\title{
Jaccoud-type lupus arthropathy: practical classification criteria
}

\author{
Mittermayer Santiago (10) 1,2
}

To cite: Santiago M. Jaccoudtype lupus arthropathy: practical classification criteria. Lupus Science \& Medicine 2020;7:e000405. doi:10.1136/ lupus-2020-000405

Received 7 April 2020 Revised 15 April 2020 Accepted 20 April 2020
Check for updates

(C) Author(s) (or their employer(s)) 2020. Re-use permitted under CC BY-NC. No commercial re-use. See rights and permissions. Published by BMJ.

${ }^{1}$ Department of Rheumatology, UFBA, Salvador, Brazil

2Department of Rheumatology, Escola Bahiana de Medicina e Saude Publica, Salvador, Brazi

Correspondence to Dr Mittermayer Santiago; Mbsantiag02014@gmail.com
To the Editor,

In 1869, François-Sigismond Jaccoud $^{1}$ described a young patient with rheumatic fever (RF) and chronic joint deformities. As homage to this physician, these deformities are known as Jaccoud's arthropathy (JA). Classical deformities observed in JA, such as swan neck, thumb subluxation, ulnar deviation and 'boutonniere', are similar to those seen in rheumatoid arthritis (RA) but are characteristically 'reducible' to passive movement. Moreover, on plain radiographs, there are no joint erosions. As RF has now become rare, JA has been described in association with several other disorders, particularly SLE. Although less common, it has also been described in other diffuse connective tissue disorders (DCTDs) such as systemic sclerosis, polymyositis, Sjogren's syndrome and vasculitis, as well as neoplastic diseases and even in normal individuals.

Although a 'reducible' pattern of arthropathy is observed in the majority of JA cases, in most advanced cases, the joints may become fixed, sometimes referred as to 'severe $\mathrm{JA}^{\text {' }}{ }^{2}$ which is clinically difficult to distinguish from RA. In such situations, misdiagnosis is common, with dangerous consequences.

Having a set of classification criteria for JA is mandatory for two main reasons, namely: (A) standardising patients for future clinical trials within a specific disease, for example, SLE; and (B) distinguishing patients with SLE and JA from those with RA, because the therapeutic approach may be different for both. Unfortunately, none of the former proposed criteria have yet to be validated.

The first attempt to differentiate JA secondary to RA from RA was made by Bywaters $^{3}$ and consisted of a history of acute RF attacks; gradual development of joint deformity, similar to swan neck and ulnar deviation, correctable by voluntary effort in the early stage; tendon crepitus generally disease inactive; and the presence of a hook-like erosion.
Later, Murphy and Staple ${ }^{4}$ proposed similar criteria but added some features, such as the absence of rheumatoid factor.

In SLE, the first criteria for JA were developed by Alarcón-Segovia et a $\tilde{p}$, who classified deforming arthropathy in SLE as any deviation of the metacarpal finger axes. However, patients without ulnar deviation but with other deformities, such as swan neck, might not be included; and overlapping of SLE with RA (rhupus) was not distinguished from JA.

Spronk et $a l^{6}$ developed a diagnostic 'index' to define the presence of JA in patients with SLE, taking into consideration the presence of different deformities and number of involved joints. JA was considered present if 'the score of the index exceeded 5 points'. However, no joints other than the hands were assessed; additionally, limited metacarpophalangeal joint extension, which is a later sign of JA, even if present in both hands, was assigned only two points.

In 1998, van Vugt et $a l^{7}$ merged the features of the criteria of Alarcón-Segovia et $a l$ and Spronk et al and proposed three different forms of deforming arthropathy in patients with SLE: 'erosive (rhupus hand)', 'JA' and 'mild non-erosive arthropathy'. The weakness of these criteria resides in the difficulty in separating the last two subgroups.

Our previously proposed criteria for $\mathrm{JA}^{8}$ included 'reducible' deformities, the absence of erosion on plain radiograph, presence or history of articular inflammation and absence of similar deformities in other healthy members of the same family. However, patients with JA can have fixed deformities or even very aggressive forms, called 'mutilanstype' deformity with several joint subluxations, ${ }^{9}$ which were not included in those criteria. Furthermore, such criteria classified JA in general, regardless of the type of systemic disease, excluding cases of 'primary' and 'familial' forms.

Herein, we tentatively proposed a new set of classification criteria, easy and practical, aiming to define the presence of Jaccoud-type 
lupus arthropathy (JLA) to distinguish it from Jaccoudtype deformities seen in RA, other DCTDs, Parkinson's disease, Ehlers-Danlos syndrome and Marfan syndrome, as well as 'primary' and 'familial' forms of arthropathy.

Thus, for JLA, all of the below criteria should be fulfilled:

1. SLE diagnosis based on the 2019 European League Against Rheumatism (EULAR)/American College of Rheumatology (ACR) criteria. ${ }^{10}$

2. Classic joint deformities, such as 'ulnar deviation', 'swan neck', 'z-thumb', 'boutonniere' and 'hallux valgum'.

3. No erosion on plain radiograph of the joints.

4. Exclusion of RA and other DCTDs based on the newest specific EULAR and or ACR criteria; heritable disorders of the connective tissue with joint hypermobility such as, but not exclusively, Ehlers-Danlos and Marfan's syndrome; and Parkinson's disease.

The JLA may be of two types: (A) 'classical', when the deformities are 'reducible' by passive movement and (B) 'severe', when the deformities are fixed. This also accounts for very complex deformities with multiple joint subluxations ('mutilans-type JA').

We believe that the practicality of these classification criteria will easily allow for its validation in clinical studies. A validation study including individuals with several DCTDs is ongoing in our institution.

Acknowledgements The author is currently receiving a scholarship from Conselho Nacional de Desenvolvimento Científico e Tecnológico. We would like to thank Editage (www.editage.com) for English language editing.

Contributors MS designed the study and drafted the manuscript.

Funding The authors have not declared a specific grant for this research from any funding agency in the public, commercial or not-for-profit sectors.

Competing interests None declared.
Patient and public involvement Patients and/or the public were not involved in the design, or conduct, or reporting, or dissemination plans of this research. Patient consent for publication Not required.

Provenance and peer review Not commissioned; externally peer reviewed.

Open access This is an open access article distributed in accordance with the Creative Commons Attribution Non Commercial (CC BY-NC 4.0) license, which permits others to distribute, remix, adapt, build upon this work non-commercially, and license their derivative works on different terms, provided the original work is properly cited, appropriate credit is given, any changes made indicated, and the use is non-commercial. See: http://creativecommons.org/licenses/by-nc/4.0/.

ORCID iD

Mittermayer Santiago http://orcid.org/0000-0003-1299-6389

\section{REFERENCES}

1 Jaccoud FS. Sur une forme de rhumatisme chronique: Lecions de clinique medicale faites a l'hopital de la charite. Paris: Delahaye, 1869: 598-616.

2 Santiago MB, Galvão V, Ribeiro DS, et al. Severe Jaccoud's arthropathy in systemic lupus erythematosus. Rheumatol Int 2015;35:1773-7.

3 Bywaters EGL. The relation between heart and joint disease including "rheumatoid heart disease" and chronic post rheumatic arthritis (type Jaccoud). Br Heart J 1950;12:101-31.

4 Murphy WA, Staple TW. Jaccoud's arthropathy reviewed. Am J Roentgenol Radium Ther Nucl Med 1973;118:300-7.

5 Alarcón-Segovia D, Abud-Mendoza C, Diaz-Jouanen E, et al. Deforming arthropathy of the hands in systemic lupus erythematosus. J Rheumatol 1988;15:65-9.

6 Spronk PE, ter Borg EJ, Kallenberg CG. Patients with systemic lupus erythematosus and Jaccoud's arthropathy: a clinical subset with an increased $C$ reactive protein response? Ann Rheum Dis 1992;51:358-61.

7 van Vugt RM, Derksen $\mathrm{RH}$, Kater L, et al. Deforming arthropathy or lupus and rhupus hands in systemic lupus erythematosus. Ann Rheum Dis 1998;57:540-4.

8 Santiago MB. Jaccoud's arthropathy: proper classification criteria and treatment are still needed. Rheumatol Int 2013;33:2953-4.

9 Santiago MB, Machicado V, Ribeiro Daniel S Á. "Mutilans-type" Jaccoud Arthropathy. J Rheumatol 2015;42:725-6.

10 Aringer M, Costenbader K, Daikh D, et al. European League against rheumatism/american College of rheumatology classification criteria for systemic lupus erythematosus. Arthritis Rheumatol 2019;2019:1400-12. 